\title{
EFFECT OF BIOSYNTHESIZED ZN AND SE NANOPARTICLES ON THE PRODUCTIVITY AND ACTIVE CONSTITUENTS OF GARLIC SUBJECTED TO SALINE STRESS
}

\author{
El-Saber, M.M.
}

Biochemistry Unit, Department of Genetic Resources, Desert Research Center, 11753 El-Matareya, Cairo, Egypt

E-mail: dr.mahmoud_saber@yahoo.com

\begin{abstract}
$\mathrm{T}$ his study is to green synthesize zinc oxide and selenium nanoparticles ( $\mathrm{ZnO} \mathrm{NPs}$ and Se NPs) through aqueous extract of moringa leaves and confirming the synthesis by specialized equipment analysis. In addition, to study the effect of their nanoparticles on the growth, yield, active constituents, and antioxidant activity of garlic plants (Sids 40) under saline stress conditions. The size formed of ZnO NPs was $30-55 \mathrm{~nm}$ and Se NPs was $3.5-17 \mathrm{~nm}$. These nanoparticles had a positive effect on all growth and yield parameters, however; the maximum values were recorded when $\mathrm{ZnO}$ NPs applied at $2 \mathrm{ppm}$. Regarding the active constituents in garlic bulbs, the nanoparticles had an effective role in increasing total phenolic compounds and flavonoids, while Se NPs promoting these compounds, especially at $0.5 \mathrm{ppm}$. For the GC-MS analysis, it was noted that the major bioactive compounds were about 27. Moreover, nanoparticles had a high effect in increasing the phytoconstituents. As for the antioxidant activity (scavenging DPPH and $\mathrm{H}_{2} \mathrm{O}_{2}$ ), the results showed that the use of nanoparticles led to a high increase in the elimination of these free radicals. Among these, all Se NPs treatments showed the highest potential to scavenge DPPH and $\mathrm{H}_{2} \mathrm{O}_{2}$, compared with the control and $\mathrm{ZnO}$ NPs. The maximum scavenging of DPPH and $\mathrm{H}_{2} \mathrm{O}_{2}$ were recorded by Se NPs at 2 and $1 \mathrm{ppm}$, respectively.
\end{abstract}

Keywords: garlic, saline stress, green synthesis, nanoparticles, active constituents

\section{INTRODUCTION}

Salinity is a key factor in limiting crop development and yield (Siddiqui et al., 2018). Salt has a negative influence on about $20 \%$ of cultivated land and half of irrigated land around the world. Excessive salt 
deposition in the soil impedes plant growth and development (Van Zelm et al., 2020). Germination, morpho-physiological characteristics, and crop output are all hampered by salinity stress. Salinity accumulates significant amounts of $\mathrm{Na}^{+}$and $\mathrm{Cl}^{-}$, disrupting the ionic balance and causing ionic stress. Furthermore, salt induces an increase in reactive oxygen species (ROS) inside plant cells, resulting in oxidative stress (El-Saber et al., 2016 and Astaneh et al., 2018). Thus, salt leads to ionic and oxidative stress and affects plants' metabolism. In addition to ionic and oxidative stress, $\mathrm{NaCl}$ also induces severe osmotic stress. Therefore, salt stress is a serious concern in agriculture (Wani et al., 2019).

Garlic (Allium sativum L.) is one of the world's most essential products, but it's a salt-sensitive plant, so the output is limited (Astaneh et al., 2019). Garlic belongs to Alliaceae family (Allen, 2009), and is one of the most important Allium species after onion (Voigt, 2004). Garlic is a source of sulfur compounds and due to its high nutritional value, it is used as a prophylactic and therapeutic against diseases (Block, 1992). Secondary metabolites found in medicinal plants serve a significant role in the treatment of various ailments and are employed as key raw materials in the production of both traditional and modern medicine (Singh and Kumar, 2017). One of these therapeutic herbs is garlic, which minimizes a variety of diseaserelated risk factors (Ameh et al., 2013). Garlic has been proven to inhibit lipid synthesis enzymes, lower platelet aggregation, prevent lipid peroxidation of damaged erythrocytes and LDL, boost antioxidant status, and inhibit the angiotensin-converting enzyme. It also lowers cholesterol, prevents platelet aggregation, lowers blood pressure, and boosts antioxidant levels (Singh and Kumar, 2017 and Kopec et al., 2020). Garlic has recently been discovered as a repellant for several plant pests and diseases (Ramasasa, 2009).

Nanotechnology is progressing at a rapid pace, offering up new avenues for nanoparticle synthesis, characterization, and applications. Thus, nanotechnology has greatly improved the use of exogenous nanoparticles on plants to combat environmental challenges such as salt stress (Farroh et al., 2020; Mahdi et al., 2020 and El-Saber et al., 2021). The accumulation of treated salt causes osmotic stress in plants, and the application of nanoparticles helps to alleviate the osmotic stress caused by the salt. As physical and chemical procedures became more expensive, the requirement for the biosynthesis of nanoparticles grew. Chemical synthesis methods frequently result in the presence of harmful chemicals absorbed on the surface, which might have negative consequences in medical applications (Parashar et al., 2009). When it comes to biosynthesized nanoparticles made by a green synthesis process, this isn't an issue (Begum et al., 2009).

Egyptian J. Desert Res., 71, No. 1, 99-128 (2021) 
Green nanoparticle synthesis has emerged as a new trend in nanotechnology development that is both safer and more environmentally friendly. Biological agents such as bacteria, plant extracts, and fungus are used in the green synthesis process instead of dangerous chemical agents (Ahmed et al., 2016), and algae (Almeida et al., 2011). One of the benefits of green synthesis is its cost-effectiveness, as the approach uses very inexpensive components. Another benefit is the method's simplicity due to the one-step process (Vadlapudi, 2014). Several plant extracts have been used in previous green synthesis studies due to their ease of production. Various plant extracts used in the previous researches are Moringa oleifera (Matinise et al., 2017; Swetha et al., 2019 and El-Sayed et al., 2020), Ficus religiosa (Kirtee et al., 2013), Memecylon umbellatum (Arunachalam et al., 2013), Macrotyloma uniflorum (Aromal et al., 2012), Brevibacterium casei (Kalishwaralal et al., 2010), honey (Philip, 2010), Citrus limon, Citrus reticulate, Citrus sinensis (Sujitha and Kannan, 2013) and Piper pedicellatum (Tamuly et al., 2013).

Zinc $(\mathrm{Zn})$ is the most abundant micronutrient, playing a critical role in plant growth and development, as well as various metabolic reactions and RNA and DNA biosynthesis (Blasco et al., 2015). Physiological stress is caused by $\mathrm{Zn}$ deficiency, which disrupts numerous enzymatic systems, lowers growth and yield components, and elevated ROS levels (Torabian et al., 2016 and Vojodi et al., 2017). Zinc oxide nanoparticles (ZnO NPs) are bio-safe materials with effects on biological and chemical species as a result of photo-oxidation and photo-catalysis (Sirelkhatim et al., 2015).

Selenium (Se) is an essential trace element for all living things. Also, Bio-Se NPs are relatively new due to their high degradability, low toxicity, and ability to clear from the body (Abbas and Abou Baker, 2020). Selenium and its nanoparticles (Se NPs) are used in a variety of ways and have a strong biological activity (Zhang et al., 2005), including antihydroxyl radical property (Gao et al., 2002) and a protective effect against the oxidation of DNA (Huang et al., 2003). It has been also reported that Se NPs have better bioavailability and less toxicity than other organic and inorganic selenocompounds (Chiou and Hsu, 2011).

Herein, the objective of this study is the biosynthesis of Bio- $\mathrm{ZnO}$ and Se NPs using the reducing power of moringa leaves extract as the natural precursor and their effects on productivity and active constituents of garlic subjected to saline stress. 


\section{MATERIALS AND METHODS}

\section{Plant Material and Experimental Design}

This experiment was carried out at the field station of the experimental farm of Desert Research Center, Ras-Sudr Research Station (an area of saline stress), South Sinai, Egypt, during the winter seasons of $2019 / 2020$ and 2020/2021, to assess up the efficacy of the application of $\mathrm{ZnO}$ NPs and Se NPs in alleviating the adverse effects of salt stress on growth, yield and active constituents of the garlic crop. Garlic bulbs cv. Sids 40 was planted on the first of October in rows; $1 \mathrm{~m}$ width under drip irrigation system. Every row contains three lines; $10 \mathrm{~cm}$ apart between cloves and the plot area was $10 \mathrm{~m}^{2}$. Garlic cloves were grown under salinity soil $(6321 \mathrm{ppm})$ and irrigation water $(7556 \mathrm{ppm})$. All other agricultural practices were followed according to the recommendations of Ras Sudr region. Irrigated water from the well and soil were analyzed and presented in table (1).

Table (1). Water and soil chemical analyses.

\begin{tabular}{cccccccccc}
\hline \multirow{2}{*}{$\mathbf{p H}$} & $\begin{array}{c}\mathbf{E C} \\
\mathbf{p p m}\end{array}$ & \multicolumn{4}{c}{ Cations (meq/l) } & \multicolumn{5}{c}{ Anions (meq/l) } \\
\cline { 3 - 9 } & $\mathbf{C a}^{++}$ & $\mathbf{M g}^{++}$ & $\mathbf{N a}^{+}$ & $\mathbf{K}^{+}$ & $\mathbf{C O}_{3}^{-}$ & $\mathbf{H C O}_{3}^{-}$ & $\mathbf{C l}^{-}$ & $\mathbf{S O}_{4}^{--}$ \\
\hline \multicolumn{8}{c}{ Water analysis } \\
\hline 8.52 & 7556 & 20.11 & 14.66 & 128.32 & 2.31 & - & 7.50 & 105.1 & 41.6 \\
\hline \multicolumn{8}{c}{ Soil analysis } \\
\hline 8.72 & 6321 & 5.8 & 4.5 & 96.35 & 1.56 & - & 5.63 & 67.5 & 28.4 \\
\hline
\end{tabular}

The experiment included two treatments of nanoparticles $\mathrm{ZnO}$ NPs (30-55 nm) and Se NPs (3.5-17 nm) with three levels compared with control as follows:

- Control (without nanoparticles)

- Zinc oxide nanoparticles (ZnO NPs) at 0.5, 1 and 2 ppm

- Selenium nanoparticles (Se NPs) at 0.5, 1 and $2 \mathrm{ppm}$

Each concentration was foliar sprayed in the early morning as a sonicated emulsion on plants at a rate of 400 liters per faddan after 1 and 2 months from sowing. A sample of three plants from each treatment were collected after 150 days of planting to assess number of leaves per plant, plant height, leaf fresh and dry weights. The bulbs were harvested at full maturity stage (190 days from the clove sowing) with three samples of each experimental treatment, to determine the yield and its component characters

Egyptian J. Desert Res., 71, No. 1, 99-128 (2021) 
i.e. total yield, average clove weight and number of cloves per bulb. Garlic bulb was separated into cloves followed by peeling and slicing. Afterwards, drying was carried out in a tunnel drier at $40^{\circ} \mathrm{C}$ for $24 \mathrm{~h}$. The dried garlic flakes were ground to a fine powder using a grinder. Later, the powder was stored in air tight glass jars at room temperature $\left(25-30^{\circ} \mathrm{C}\right)$ for further investigations.

\section{Nanoparticles Preparation and Characterization}

\subsection{Preparation of Moringa oleifera leaf extract}

Ten grams of Moringa oleifera leaves (obtained from greenhouse of

Desert Research Center, Cairo, Egypt) were washed thoroughly with distilled water and both surfaces of leaves were sterilized using alcohol by gentle rubbing. These leaves were heated for $40 \mathrm{~min}$ in $100 \mathrm{ml}$ of distilled water at $50^{\circ} \mathrm{C}$. Then the extract was filtered with Whatman no. 41 filter paper. The filtrate was stored in a cool and dry place.

2.2. Synthesis of zinc oxide nanoparticles ( $\mathrm{ZnO}$ NPs) using moringa extract

Zinc oxide nanoparticles were prepared by the mixing $10 \mathrm{ml}$ of Moringa oleifera leaf extract with the $90 \mathrm{ml}$ of $0.05 \mathrm{mM}$ zinc nitrate hexahydrate $\left[\mathrm{Zn}\left(\mathrm{NO}_{3}\right)_{2} \cdot 6 \mathrm{H}_{2} \mathrm{O}\right]$ solution. The mixture was heated on a hot plate at $80^{\circ} \mathrm{C}$ for $30 \mathrm{~min}$ with the continuous stirring. The presence of white colored particles indicated the formation of nanoparticles. The particles thus formed were centrifuged and the pellets were collected. The pellet was dried and calcinated for $2 \mathrm{~h}$ at $300^{\circ} \mathrm{C}$. White-colored nanoparticles were obtained as per protocol followed by Pal et al. (2018).

2.3. Synthesis of selenium nanoparticles (Se NPs) using moringa extract

For the ecofriendly synthesis of selenium nanoparticles, dissolve selenious acid $\left(\mathrm{H}_{2} \mathrm{SeO}_{3}, 0.013 \mathrm{~g}, 0.01 \mathrm{mmol}\right)$ in $90 \mathrm{ml}$ deionized water was added to moringa extract (filtrate, $10 \mathrm{ml}$ ), with continuous stirring and heating at $60^{\circ} \mathrm{C}$ for $1 \mathrm{~h}$; forming in-situ after that $200 \mu 1$ of $40 \mathrm{mM}$ ascorbic acid was added as a catalyst and the ruby red Se NPs were suspended according to Ramamurthy et al. (2013).

\subsection{Characterization of $\mathrm{ZnO}$ and Se NPs}

\subsubsection{Ultraviolet-Visible (UV-VIS) spectra}

UV-VIS (Shimadzu spectrophotometer) has been used to follow the formation of zinc oxide and selenium nanoparticles in the moringa extract aqueous solution. The UV-Vis spectra were recorded between $300-700 \mathrm{~nm}$.

\subsubsection{Transmission Electron Microscopy (TEM)}

The shape and size of ZnO NPs and Se NPs were practically obtained using High-Resolution Transmission Electron Microscopy 
(HRTEM) JEOL (JEM-2100 TEM). Specimens for TEM measurements were prepared by placing a drop of colloidal solution on 400 mesh carbon coated copper grid and evaporating the solvent in the air at room temperature. The program (image J) using to calculate the average size of nanoparticles.

\section{Active Constituents in Garlic Bulbs}

\subsection{Estimation of total phenolic content}

Appropriately diluted sample in $1 \mathrm{ml}$ was mixed with $1 \mathrm{ml}$ of $95 \%$ ethanol, $5 \mathrm{ml}$ of distilled water and $0.5 \mathrm{ml}$ of $50 \%$ Folin-Ciocalteu reagent. The mixture was allowed to react for $5 \mathrm{~min}$ and $1 \mathrm{ml}$ of $5 \% \mathrm{Na}_{2} \mathrm{CO}_{3}$ was added. Thereafter, it was thoroughly mixed and placed in the dark for $1 \mathrm{~h}$ and the absorbance was measured at $765 \mathrm{~nm}$ using UV-Visible spectrophotometer. A gallic acid standard curve was obtained for concentrations $(50,100,150,200,250 \mathrm{mg} / \mathrm{ml})$ of ethanol for the calculation of polyphenol content according to Suleria et al. (2012).

\subsection{Estimation of total flavonoids}

Total flavonoids content was determined by using spectrophotometer following the protocol of Bozin et al. (2008). The sample $(100 \mathrm{mg})$ was added to $0.4 \mathrm{ml}$ distilled water followed by $\mathrm{NaNO}_{2}(0.03 \mathrm{ml}$, $5 \%)$. After $5 \mathrm{~min}$ at $25^{\circ} \mathrm{C}, \mathrm{AlCl}_{3} \cdot 6 \mathrm{H}_{2} \mathrm{O}(0.03 \mathrm{ml}, 10 \%)$ was added, followed by aqueous $\mathrm{NaOH}(0.2 \mathrm{ml}, 1 \mathrm{M})$ after $6 \mathrm{~min}$. The mixture was diluted with water to $1 \mathrm{ml}$ and the absorbance at $510 \mathrm{~nm}$ was read and the total flavonoids content was estimated.

\subsection{Identification of active constituents in garlic cloves}

\subsubsection{Extraction of active constituents}

For Gas chromatography-Mass Spectrometry (GC-MS) profiling, garlic cloves collected were ground into a powder with the help of a grinder. The dried material $(5 \mathrm{~g}$ ) was extracted using chloroform (anhydrous, $\geq 99 \%$, contains $0.5-1.0 \%$ ethanol as a stabilizer) as a solvent. Then the extract was evaporated to dryness according to Thomas et al. (2013).

\subsubsection{GC-MS conditions}

The GC/MS analysis was performed using a Thermo Scientific, Trace GC Ultra / ISQ Single Quadrupole MS, TG-5MS fused silica capillary column (30 m, $0.251 \mathrm{~mm}, 0.1 \mathrm{~mm}$ film thickness). For GC/MS detection, an electron ionization system with ionization energy of $70 \mathrm{eV}$ was used. Helium gas was used as the carrier gas at a constant flow rate of $1 \mathrm{ml} / \mathrm{min}$. The injector and MS transfer line temperature was set at $280^{\circ} \mathrm{C}$. The oven temperature was programmed at an initial temperature of $50^{\circ} \mathrm{C}$ (hold $2 \mathrm{~min}$ ) to $150^{\circ} \mathrm{C}$ at an increasing rate of $7^{\circ} \mathrm{C} / \mathrm{min}$ then to $270^{\circ} \mathrm{C}$ at an increasing rate of $5^{\circ} \mathrm{C} / \mathrm{min}$ (hold $2 \mathrm{~min}$ ) then to $310^{\circ} \mathrm{C}$ as a final temperature at an increasing rate of $3.5^{\circ} \mathrm{C} / \mathrm{min}$ (hold $10 \mathrm{~min}$ ). The quantification of all the

Egyptian J. Desert Res., 71, No. 1, 99-128 (2021) 
identified components was investigated using a percent relative peak area. Tentative identification of the compounds was performed based on the comparison of their relative retention time and mass spectra with those of the NIST, WILLY library data of the GC/MS system.

\section{Antioxidant Activity}

\subsection{DPPH radical scavenging assay}

The method described by Oktay et al. (2003) was used with some changes for the DPPH 1,1-Diphenyl-2-picrylhydrazyl radical 2,2-Diphenyl$1-(2,4,6$-trinitrophenyl) hydrazyl (DPPH) test. Four $\mathrm{ml}$ of a $0.004 \%$ solution of DPPH in $80 \%$ methanol was mixed with $1 \mathrm{ml}$ of methanolic extract. The reaction mixture was vortexed and left in the dark at room temperature for $30 \mathrm{~min}$. The absorbance of the mixture was measured spectrophotometrically at $517 \mathrm{~nm}$. The ability to scavenge DPPH radical was calculated by the following equation:

$$
(\mathrm{RSC} \%)=\left(\mathrm{A}_{\text {Blank }}-\mathrm{A}_{\text {Sample }}\right) /\left(\mathrm{A}_{\text {Blank }}\right) \times 100
$$

Where, $(\mathrm{RSC} \%)=\mathrm{DPPH}$ radical scavenging activity $(\%)$

$A_{\text {Blank }}$ is the absorbance of DPPH radical+ methanol $(1 \mathrm{ml} \mathrm{DPPH}$ and $3 \mathrm{ml}$ methanol), Asample is the absorbance of DPPH radical + sample extract

\subsection{Hydrogen peroxide scavenging assay}

Garlic extracts ability to scavenge hydrogen peroxide was tested using the method of Ruch et al. (1989). A solution of hydrogen peroxide (40 $\mathrm{mM}$ ) in phosphate buffer ( $\mathrm{pH} 7.4$ ) was produced and concentrations were measured spectrophotometrically at $230 \mathrm{~nm}$. After 19 min, extracts (25-50 $\mathrm{g} / \mathrm{ml})$ in distilled water were added to a hydrogen peroxide solution $(0.6 \mathrm{ml}$, $40 \mathrm{mM}$ ) and hydrogen peroxide absorbance at $230 \mathrm{~nm}$ was measured against a blank solution in phosphate buffer without hydrogen peroxide. The percentage of scavenging of hydrogen peroxide of extracts and standard compounds was calculated using the following equation:

$$
\% \text { Scavenged }\left(\mathrm{H}_{2} \mathrm{O}_{2}\right)=\left[\left(\mathrm{A}_{0}-\mathrm{A}_{1}\right) / \mathrm{A}_{0}\right] \times 100
$$

Where: $A_{0}$ was the absorbance of the control and $A_{1}$ was the absorbance of garlic extracts.

\section{Statistical Analysis}

All the statistical analysis was performed using SPSS v 16.0 (SPSS Inc., 2007, Chicago, IL, USA) software program. The least significant difference (LSD) test was used to detect the significant differences among the items at a probability level (0.05) according to Gomez and Gomez (1984). 


\section{RESULTS AND DISCUSSION}

\section{Characterization of $\mathrm{ZnO}$ and Se Nanoparticles 1.1. UV-visible spectrophotometer analysis}

Fig. (1a and b) shows the UV-V is spectra of green synthesized $\mathrm{ZnO}$ and Se NPs by Moringa oleifera leaves extract. From the spectra, a clear dependence in the optical properties can be observed as a function of used extract solution. Fig. (1a) shows that the UV-Vis spectra of green synthesized $\mathrm{ZnO}$ NPs demonstrated a significant peak of $358.7 \mathrm{~nm}$, which is mostly distinguished by ZnO NPs. While, Se NPs presented at 2 bands of absorption at 299 and $400 \mathrm{~nm}$ typical to selenium zerovalent (Banaee et al., 2019 and Ibrahim et al., 2019). Zn and Se metal ion reduction, since the plant extract, contains reduced sugars or phenolic compound and terpenoids (Ibrahim 2020). The synthesized $\mathrm{ZnO}$ and Se nanoparticles have been stabilized by reducing organic compounds (Gholizadeh et al., 2019).

\subsection{Fourier Transform Infrared Spectroscopy (FT-IR)}

Fourier transform infrared spectroscopy was used for the measurement of absorption of infrared radiations (IR) by the sample, and the results are shown by the means of a wavelength (Fig. 2a and b). This spectroscopy was carried out to identify the possible biomolecules in Moringa oleifera leaf extract responsible for capping leading to efficient stabilization of the ZnO and Se NPs. The FTIR spectra of ZnO NPs (Fig. 2a) shows the presence of bonds due to $\mathrm{OH}$ stretching frequency around 3480 $\mathrm{cm}^{-1}$. However, peaks at $2925 \mathrm{~cm}^{-1}$ and $2849 \mathrm{~cm}^{-1}$ are attributed to the asymmetric and symmetric stretching vibrations of $\mathrm{CH}_{2}$ group, respectively. The peak at $1620 \mathrm{~cm}^{-1}$ results from the stretching bands of $\mathrm{C}=\mathrm{O}$ functional groups, and these results were confirmed by Rastogi and Arunachalam (2011) and Pal et al. (2018). The peak at around $1383 \mathrm{~cm}^{-1}$ present in $\mathrm{ZnO}$ signified amide band of the random coil of protein (Cai and Sing, 2004). The peak at $710 \mathrm{~cm}^{-1}$ indicates the stretching vibrations representing the chemical components or metabolic products. Similarly, the FTIR spectra of Se NPs (Fig. 2b) show FT-IR spectrum exhibits the characteristic features of fingerprint band. A broad vibration peak at $3450 \mathrm{~cm}^{-1}$ corresponds to $\mathrm{OH}$ stretch of alcohols and phenols groups. Absorption peak at 2962 and 2765 $\mathrm{cm}^{-1}$ represents the $\mathrm{C}-\mathrm{H}$ stretch of alkynes groups. The small band at 2318 $\mathrm{cm}^{-1}$ corresponds nitro compounds (N-O asymmetric stretch) present in the compound. The strong band at 1567 and $1478 \mathrm{~cm}^{-1}$ relates to the aromatics and alkanes ring $(\mathrm{C}-\mathrm{C}$ and $\mathrm{C}-\mathrm{H}$ stretching). The small vibrational peaks 1372 to $1248 \mathrm{~cm}^{-1}$ corresponds to the bending $(\mathrm{C}-\mathrm{H}, \mathrm{C}-\mathrm{N}, \mathrm{O}-\mathrm{H}, \mathrm{C}-\mathrm{X}$ and $\mathrm{C}-\mathrm{N}-\mathrm{C})$ stretches attributed to alkanes, amines and carboxylic groups. However, these functional groups are confirms the involvement of different

Egyptian J. Desert Res., 71, No. 1, 99-128 (2021) 
reducing and stabilizing agents in the synthesis of Se NPs (Kannan et al., 2014; Pal et al., 2018 and Zafar et al., 2021). The infrared spectrum identified the major components present in organic materials.

\subsection{Transmission Electron Microscopy (TEM)}

Fig. ( $3 a$ and $b$ ) shows the shape, size, as well as size distribution of $\mathrm{ZnO}$ and Se NPs fabricated by Moringa oleifera. The TEM image exhibits a good distribution of spherical ZnO NPs without any aggregation (Fig. 3a). Moreover, image analysis (Fig. 3aI) demonstrated that the size of ZnO NPs was in the range of 30.0 to $55.0 \mathrm{~nm}$. The characterization of the colloidal selenium nanoparticles was also confirmed by TEM as clearly shown in Fig. (3b). The synthesized selenium nanoparticles obtained by this green method have a spherical morphology with an average size of about 3.5-17 nm, with some clusters (Fig. 3aI). The average particle size was measured using the Image J program.
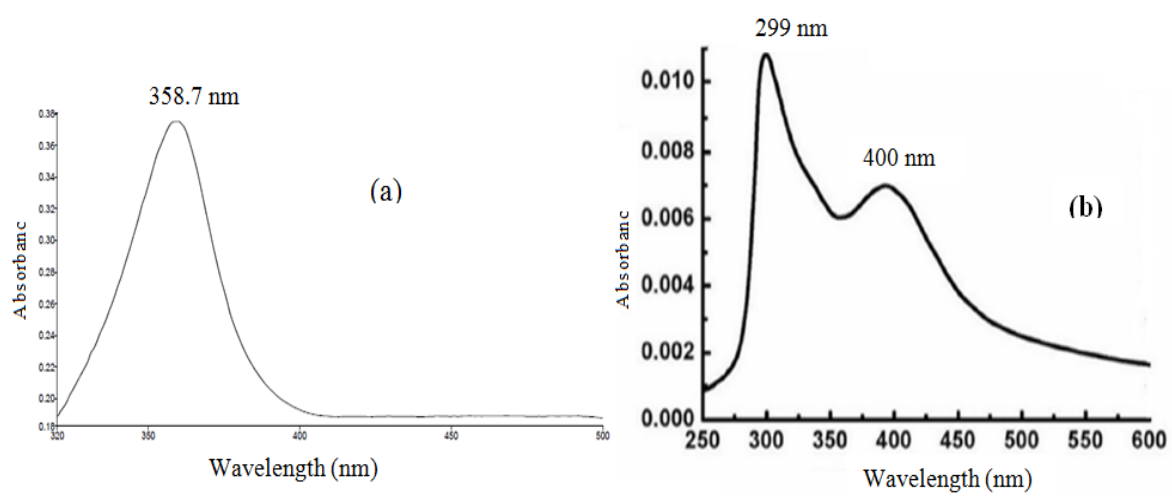

Fig. (1). UV-Visible of (a) ZnO NPs and (b) Se NPs.
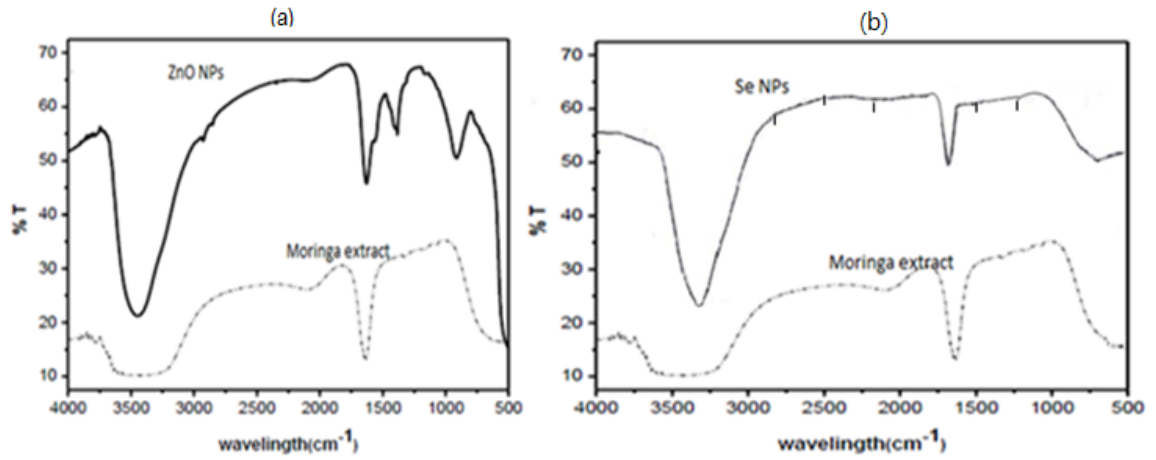

Fig. (2). FTIR spectra of (a) ZnONPs and (b) SeNPs synthesized by Moringa oleifera leaf extract. 

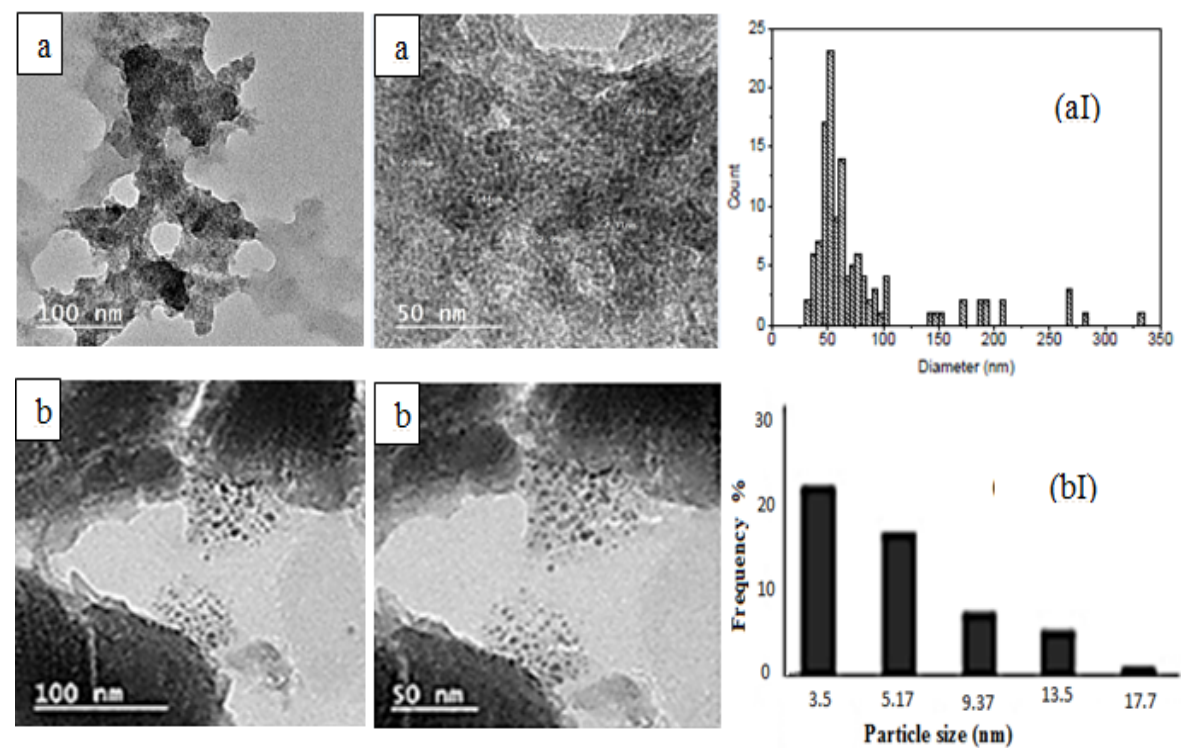

Fig. (3). Transmission electron microscope for (a) ZnO NPs, (b) Se NPs, particle size distributions for (aI) ZnO NPs and (bI) Se NP.

\section{Effect of ZnO NPs and Se NPs on Growth and Yield Parameters}

\subsection{Growth parameters}

Data in fig. (4) show the effect of $\mathrm{ZnO}$ NPs and Se NPs on vegetative growth parameters, i.e. plant height, number of leaves per plant, leaves fresh and dry weights under saline stress conditions. A foliar spraying of $\mathrm{ZnO}$ NPs and SeNPs showed the positive effect on all growth parameters compared with control. The maximum values of growth parameters were recorded when garlic plants (Sids-40) treated with ZnO NPs and Se NPs at 2 ppm. Also, data showed that ZnO NPs treatments were better than Se NPs. In this regard, application of zinc, and selenium to plants as essential microelements could play major roles in growth, metabolism and development under saline stress (Thalooth et al., 2006; Salama et al., 2012 and Kamran et al., 2020). Selenium has been considered as a beneficial element for crop production, which plays an important role in physiobiochemical processes (Iqbal et al., 2015 and Sieprawska et al., 2015). Although higher plants do not require Se for their growth and development (Hasanuzzaman et al., 2011 and Versini et al., 2016), supplementation of Se at lower dosages not only protects plants from ROS induced oxidative damage by activating the antioxidative mechanisms (Iqbal et al., 2015), but 
also improves the Se content in the edible parts of the crop plants (Babalar et al., 2019).
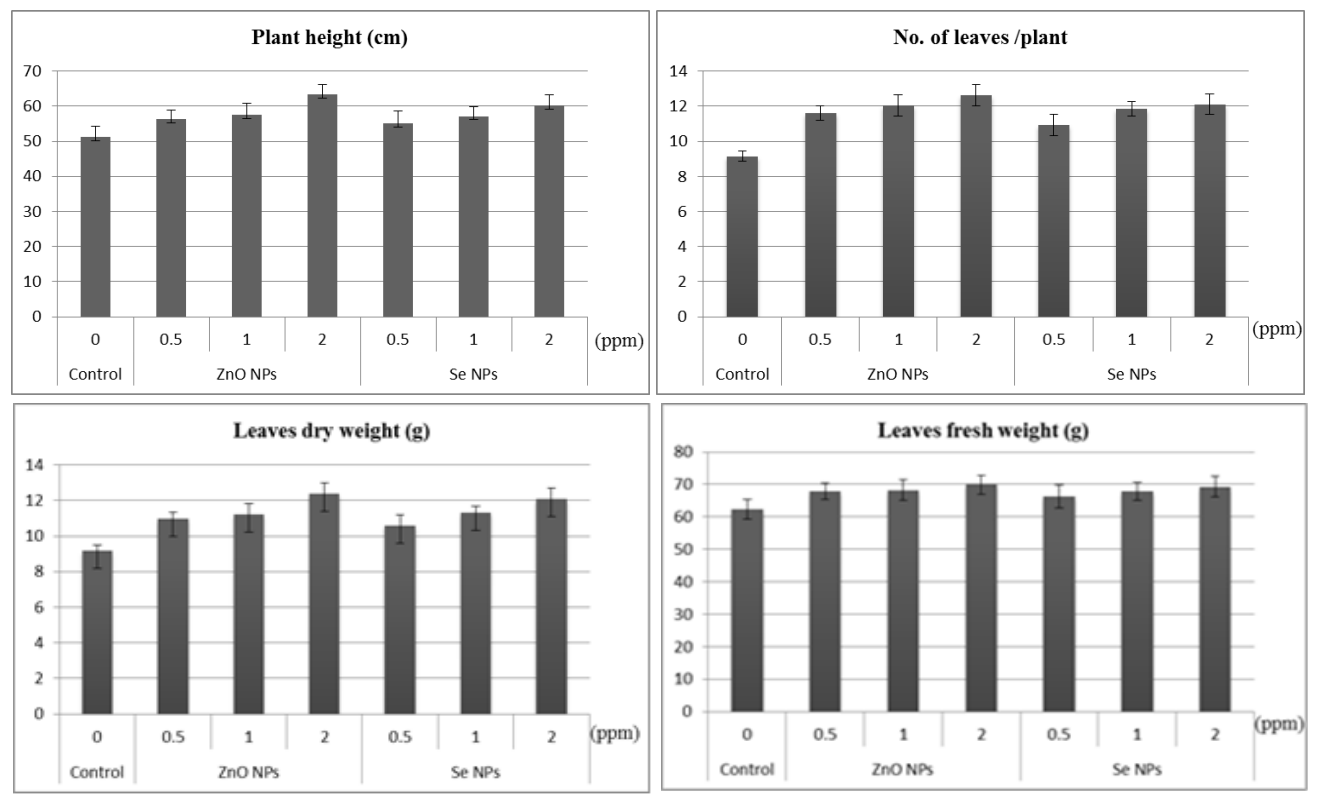

Fig. (4). Effect of ZnO NPs and Se NPs on growth parameters of garlic (Sids 40) under saline stress conditions.

\subsection{Yield parameters}

Fig. (5) shows clearly the yield parameter of the garlic plants (Sids 40 ); i.e. number of cloves/bulb, average clove weight and yield (ton/fed) under saline stress conditions. The data illustrated that ZnO NPs and Se NPs had a positive effect on garlic yield and yield component, compared with the control. The highest values of all yield parameter were recorded when garlic plants treated with zinc oxide and selenium nanoparticles at $2 \mathrm{ppm}$. These results might be taken place due to the enhancing happened for the growth traits as a result of spraying ZnO NPs and Se NPs on garlic plants, which in turn reflected this increasing in yield and its component traits. The obtained result is in accordance with that obtained by Al-Zohiri (2009) on garlic crop. Garlic is one of the most important products around the world, but it is a salt-sensitive plant which limits its production (Astaneh et al., 2019). However, attempts to improve yield under stress conditions by adding the requirements from essential elements have been largely unsuccessful. 
Therefore, a well-focused approach combining the molecular, physiological, biochemical and metabolic aspects of salt tolerance is essential to develop crop varieties to be more tolerant. One of the protective methods is the use of selenium, which can increase stress resistance by improving growth, thereby reducing the harmful effects of abiotic stresses (Astaneh et al., 2018). Likewise, zinc played critical role in protecting vital cellular components as photosynthetic pigments by preventing their oxidation (Cakmak, 2000). Meanwhile, the application of $\mathrm{ZnO}$ and Se NPs further helps to adjust the salt induced osmotic stress.

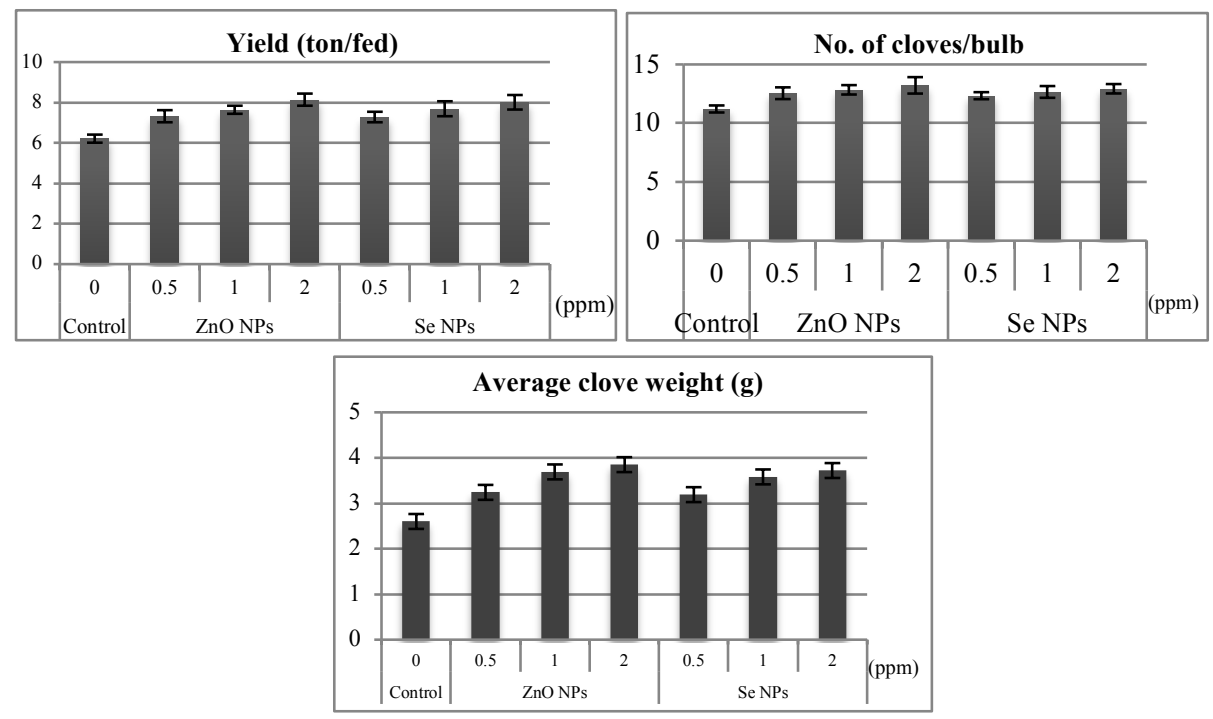

Fig. (5). Effect of ZnO NPs and Se NPs on yield parameters of garlic (Sids 40) under saline stress conditions.

\section{Effect of ZnO NPs and Se NPs on Active Constituents in Garlic Bulbs 3.1. Total phenolics}

Data presented in fig. (6a) show the effect of ZnO NPs and Se NPs on the total phenolic compounds in bulbs of garlic plants under saline stress conditions. It was observed that, $\mathrm{ZnO}$ NPs and Se NPs led to an increase in total phenolic compounds compared with the control. The maximum values were recorded when plants applied with Se NPs as compared with the control and $\mathrm{ZnO}$ NPs. In this connection, the highest mean value of phenolic compounds was detected by the low concentration of Se NPs $(0.5 \mathrm{ppm})$. In this regard, phenolic compounds are important plant constituents that are required for the synthesis of lignin and pigments, they also provide structural

Egyptian J. Desert Res., 71, No. 1, 99-128 (2021) 
integrity and scaffolding support to plants. In higher plants, these compounds are considered as secondary metabolites that, among others, are implicated in the plant defense-related machinery (Boudet, 2007 and Gill and Tuteja, 2010). Moreover, phenolics are the widest spread secondary metabolite in plant kingdom. These diverse groups of compounds have received much attention as potential natural antioxidant in terms of their ability to act as both efficient radical scavengers and metal chelator. It has been reported that the antioxidant activity of phenol is mainly due to their redox properties, hydrogen donors and singlet oxygen quenchers (Narendhirakannan and Rajeswar, 2010). Polyphenols are among the major contributors to the antioxidant activity of plant-based materials. The antioxidant capacity of these components is accredited to the redox potential, which allows them to act as reducing agents, singlet oxygen quenchers and hydrogen donors. Therefore, their quantification in various foodstuffs is necessary to assess the nutraceutical worth of the particular food (Awan et al., 2019). Furthermore, Se has been demonstrated to regulate plant growth by strengthening the stress tolerance mechanisms such as antioxidant and secondary metabolite metabolism (Jiang et al., 2017). The related results agree with the finding of Reda et al. (2014) in faba bean plants. Jan and Hadi (2015) reported that zinc foliar applications significantly increased the phenolic content in sunflower as compared to the control plants. Exogenous application of $\mathrm{Zn}$ counteracted the harmful effects of salinity on nonenzymatic scavenging systems. Application of $\mathrm{Zn}$-Chelated increased the total phenols content in the leaves of two maize cultivars (Salama et al., 2015).

\subsection{Total flavonoids}

Flavonoid contents in bulbs of garlic plants treated with $\mathrm{ZnO}$ NPs and Se NPs under salinity stress conditions are illustrated in fig. (6b). Data show that, all nanoparticles treatments increased flavonoid contents in garlic bulbs compared with the control under salinity stress. The Se NPs treatments were better in accumulation of flavonoids than ZnO NPs. The maximum value was recorded by Se NPs $(0.5 \mathrm{ppm})$, and ZnO NPs (2 ppm), respectively. In the context, flavonoids are prominent secondary plant metabolites, which are ubiquitous in photosynthesizing cells. Allium species are among the good sources of flavonoids and act as health benefactors (Slimestad et al., 2007). The results of the present investigations are in consistence with the findings of Bozin et al. (2008), who reported that polar fractions of garlic contain considerable antioxidant potential. Although most antioxidant activities from plant sources are derived from phenolic-type compounds (Cai et al., 2004), these effects do not always correlate with the presence of large quantities of 
phenolics. The decreases of flavonoids contents are most probably caused by the increase of sulphur compounds and terpenoid substances present in the essential oil of mature garlic bulbs (Bozin et al., 2008). With respect to, the important role of ZnO NPs and Se NPs to accumulate the phenolic and flavonoids in plant under saline stress. The beneficial effect of Se at low concentrations has been well documented in potato (Turakainen et al., 2004). The protective role of low Se concentrations in plants exposed to stressful conditions in most cases has been attributed to activation of antioxidative defense systems in plant cells (Kaur et al., 2014 and Sieprawska et al., 2015).

Under saline stress conditions, the reactive oxygen species (ROS) accumulation in plants damages DNA, decreases photosynthesis, and interferes with ion absorption (Ayad et al., 2010). It seems that the increase in phenolic and flavonoid biosynthesis and content with foliar sprayed plants are correlated with the positive effects of $\mathrm{Zn}$ on the production of these macromolecules. It has been suggested that $\mathrm{Zn}$ significantly influences the expression of phenolic biosynthesis pathway genes through berry development (Song et al., 2015). Zinc plays critical roles in the defense system of cells against ROS and stimulates the production of several antioxidant enzymes and compounds which have crucial roles in the prevention of the membrane lipid peroxidation and even prevent the structural modifications in the proteins and nucleic acids that are commonly prevailing under an oxidative situation (Mehrabani et al., 2017).

\subsection{Active compounds}

Results of GC-MS analysis are described in tables (2 and 3). It was noted that 54 compounds appeared, but the basic compounds were about 27. The major bioactive compounds resulting from the garlic as affected by $\mathrm{ZnO}$ NPs and Se NPs under saline stress conditions (Table 2) were, 2,12dibromo-7-phenyl-5,6,8,9- tetrahydrobenz [a,j] anthracene-14-carboxylic acid; propene-1,1-D2; methane, chlorofluoro; n-octylacetate; 3-butyn-1-ol; N,NBis [(propoxyethyl) oxy] annulene; spiro [5-vinyl-Nphenylsulfonylpyrrolidine-3,3-'benzofuran]; 2-(5-methylthio-3-oxopentyl) cyclohexanone; hexadecanoamide; 1-phellandrene; benzene, eicosyl; docosane; pentyl trichloroacetate; 4-(1-hydroxyethyl)1,6,7tris(2-methoxy carbonyl ethyl) 2,3,5,8-tetramethylporphyrin; 2,2,7,7-tetraadeutero hexamethylene sulphide; methylsulfinato $(5,10,15,20$ tetraphenylporphyrinato) iron; 9-octadecenoic acid, methyl ester; $(5,10,15,20$ tetraphenyl[2-(2)H1]prophyrinato) zinc (II); ipropyl-3-(phenylamino)2phenylseleno)3-(phenyl)propanoate; 2,9-bis(5-tertbutyl2hydroxy-3pyridylphenyl) 1,1-0-phenanthroline; 1-acetyl-4,4-bis[4-(3-bromopropoxy)3,5-dimethoxyphenyl] piperidine; 13,14-bis(methylsulfonyl) pseudaconine;

Egyptian J. Desert Res., 71, No. 1, 99-128 (2021) 
2,7,12,17-tetraethyl-3,5:8,10:

13,15:18,20-tetrakis $(2,2-$

dimethylpropano)porphyrin;4,5,6,7-tetrakis(pchlorophenoxy) 1,2-

diiminoisoindoline; 5-acetoxyoctaethylporphyrin; N,N-bis[2-[3,5-bis (ethoxycarbonyl) phenoxy]ethyl]-p-toluenesulfonamide and acetonitrile, (dimethylamino). Data revealed that, ZnO NPs and Se NPs had appositive effect in increasing the area percent of phytoconstituents compared with the control (Table 3). The maximum peak area in garlic bulbs chloroform extract are acetonitrile,(dimethylamino); propene1,1D2; methane, chlorofluoro; noctylacetate; 3-butyn-1-ol; N,Nbis[(propoxyethyl)oxy]annulene; spiro[5vinyl-N-phenylsulfonylpyrrolidine-3,3-'benzofuran];2-(5-methylthio-3oxopentyl) cyclohexanone; methylsulfinato $(5,10,15,20$ tetraphenylporphyrinato) iron; 9-octadecenoic acid, methyl ester; ipropyl-3(phenylamino)2-(phenylseleno)3-(phenyl) propanoate; 2,2,7,7-tetraadeutero hexamethylene sulphide. In light of the results, the active compounds identified at retention times $(5.13,5.32,5.47,6.3,7.03,14.27,14.7,19.19$ and 41.54) were accumulated in plants treated with $\mathrm{ZnO}$ NPs more than Se NPs. In contrast, the active compounds identified at retention times (5.07, $5.29,5.41,9.9,12.51,44.34,50.82,51.27$ and 53.41) were higher in plants treated with Se NPs than ZnO NPs. In addition, the active compounds identified at retention time (5.41) were more in the control treatment than all $\mathrm{ZnO}$ NPs treatments, while the compounds appeared at retention time (7.03) were higher than all Se NPs treatments. In this connection, phytochemicals usually give plants its characteristic colour, odor and flavour, and consider part of its internal defense mechanism against pests, parasites and pathogens (Ibrahim et al., 2010). Ali and Ibrahim (2019) detected the presence of alkaloids in garlic bulbs. Deresse (2010) found that garlic extract exhibited activity against both gram negative and gram positive due to presence of some phytochemicals such saponins and tannins. The medicinal properties of garlic have been attributed to the abundance of sulfur-containing compounds. These compounds have also shown antifungal (Ledezma and Apitz-Castro, 2006), antibacterial (Mnayer et al., 2014), acaricidal (ElZemity et al., 2006), antiparasitic (Ayaz et al., 2008), antiviral (Romeilah et al., 2010), and insecticidal (Zhao et al., 2013) properties. 

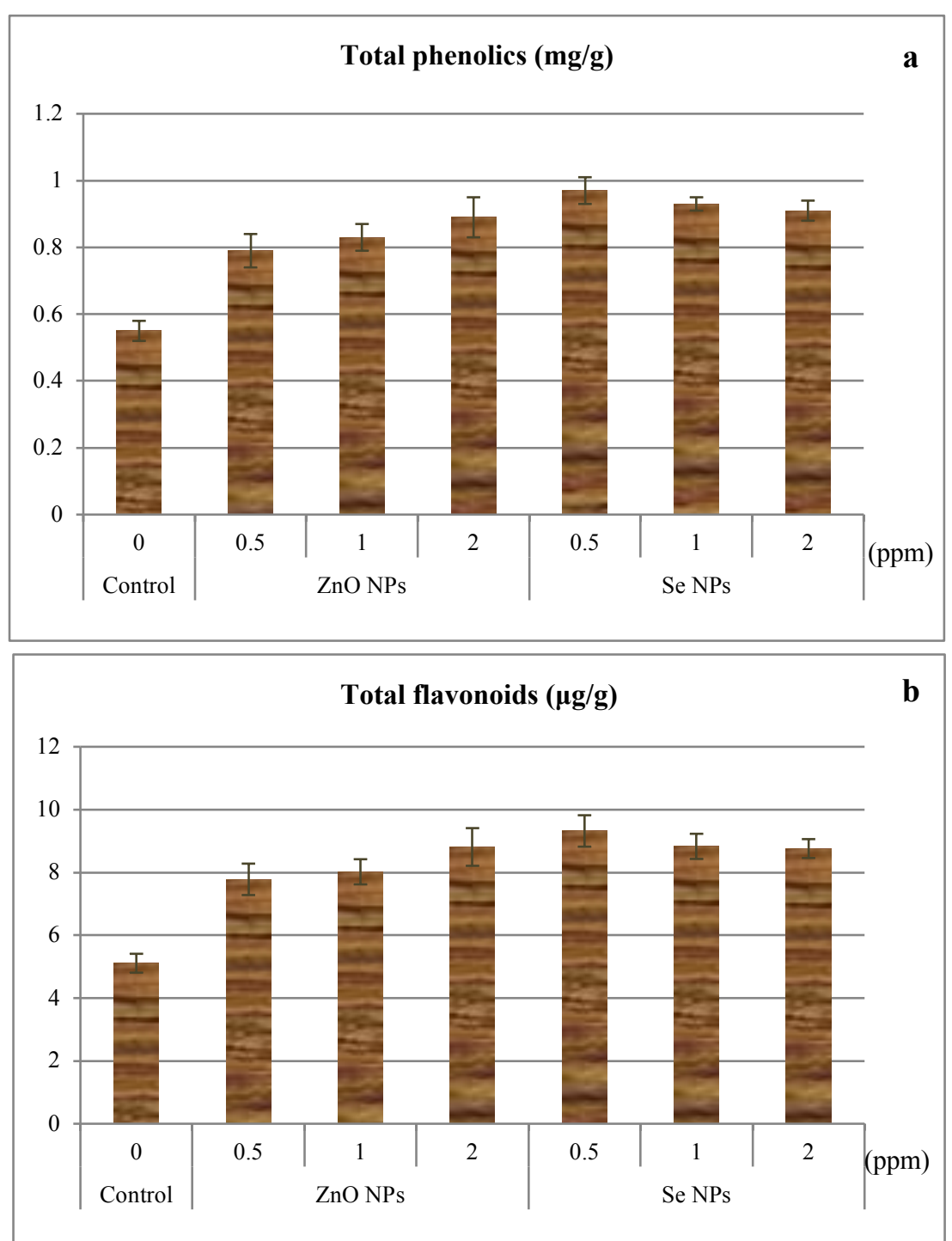

Fig. (6). Effect of ZnO NPs and Se NPs on the (a) total phenolic and (b) flavonoids in garlic bulb (Sids 40) under saline stress conditions.

Egyptian J. Desert Res., 71, No. 1, 99-128 (2021) 
Table (2). Active compounds of garlic bulb extract treated by ZnO NPs and Se NPs under saline stress conditions.

\begin{tabular}{|c|c|c|c|c|}
\hline PN & RT & Active compounds & MF & MW \\
\hline 1 & 5.07 & Acetonitrile,(dimethylamino)(CAS) & $\mathrm{C}_{4} \mathrm{H}_{8} \mathrm{~N}_{2}$ & 84 \\
\hline 2 & 5.13 & Propene1,1D2 & $\mathrm{C}_{3} \mathrm{H}_{4} \mathrm{D}_{2}$ & 42 \\
\hline 3 & 5.29 & Methane, chlorofluoro(CAS) & $\mathrm{CH}_{2} \mathrm{ClF}$ & 68 \\
\hline 4 & 5.32 & n-Octylacetate & $\mathrm{C}_{10} \mathrm{H}_{20} \mathrm{O}_{2}$ & 172 \\
\hline 5 & 5.41 & 3-Butyn-1-ol(CAS) & $\mathrm{C}_{4} \mathrm{H}_{6} \mathrm{O}$ & 70 \\
\hline 6 & 5.47 & N,NBis[(propoxyethyl)oxy] annulene & $\mathrm{C}_{38} \mathrm{H}_{36} \mathrm{~N}_{2} \mathrm{O}_{3} \mathrm{~S}_{4}$ & 696 \\
\hline 7 & 6.3 & $\begin{array}{l}\text { spiro[5-Vinyl-N-phenylsulfonylpyrrolidine-3,3- } \\
\text { 'benzofuran] }\end{array}$ & $\mathrm{C}_{19} \mathrm{H}_{19} \mathrm{NO}_{3} \mathrm{~S}$ & 341 \\
\hline 8 & 7.03 & 2-(5-Methylthio-3-oxopentyl)cyclohexanone & $\mathrm{C}_{12} \mathrm{H}_{20} \mathrm{O}_{2} \mathrm{~S}$ & 228 \\
\hline 9 & 8.87 & Hexadecanoamide & $\mathrm{C}_{16} \mathrm{H}_{33} \mathrm{NO}$ & 255 \\
\hline 10 & 9.9 & 1-Phellandrene & $\mathrm{C}_{10} \mathrm{H}_{16}$ & 136 \\
\hline 11 & 10.11 & Benzene, eicosyl(CAS) & $\mathrm{C}_{26} \mathrm{H}_{46}$ & 358 \\
\hline 12 & 12.51 & Docosane (CAS) & $\mathrm{C}_{22} \mathrm{H}_{46}$ & 310 \\
\hline 13 & 13.61 & Pentyl trichloroacetate & $\mathrm{C}_{7} \mathrm{H}_{11} \mathrm{C}_{13} \mathrm{O}_{2}$ & 232 \\
\hline 14 & 14.27 & $\begin{array}{l}\text { 4-(1-hydroxyethyl)1,6,7tris(2- } \\
\text { methoxycarbonylethyl)2,3,5,8-tetramethylporphyrin }\end{array}$ & $\mathrm{C}_{38} \mathrm{H}_{44} \mathrm{~N}_{4} \mathrm{O}_{7}$ & 666 \\
\hline 15 & 14.7 & 2,2,7,7-Tetraadeutero hexamethylene sulphide & $\mathrm{C}_{6} \mathrm{H}_{8} \mathrm{D}_{4} \mathrm{~S}$ & 116 \\
\hline 16 & 19.19 & $\begin{array}{l}\text { Methylsulfinato }(5,10,15,20- \\
\text { tetraphenylporphyrinato)iron }\end{array}$ & $\mathrm{C}_{45} \mathrm{H}_{31} \mathrm{FeN}_{4} \mathrm{O}_{2} \mathrm{~S}$ & 747 \\
\hline 17 & 20.36 & $\begin{array}{c}\text { 2,12Dibromo7pheny15- } \\
\text { 6,8,9tetrahydrobenz[a,i]anthracene-14-carboxylic Acid }\end{array}$ & $\mathrm{C}_{29} \mathrm{H}_{20} \mathrm{Br}_{2} \mathrm{O}_{2}$ & 558 \\
\hline 18 & 34.18 & 9-Octadecenoic acid,methyl ester (CAS) & $\mathrm{C}_{19} \mathrm{H}_{36} \mathrm{O}_{2}$ & 296 \\
\hline 19 & 41.04 & $(5,10,15,20$ tetraphenyl[2-(2)H1]prophyrinato)zinc(II) & $\mathrm{C}_{44} \mathrm{H}_{28} \mathrm{~N}_{4} \mathrm{Zn}$ & 676 \\
\hline 20 & 41.54 & $\begin{array}{l}\text { iPropyl-3-(phenylamino)2-(phenylseleno)3- } \\
\text { (phenyl)propanoate }\end{array}$ & $\mathrm{C}_{24} \mathrm{H}_{25} \mathrm{NO}_{2} \mathrm{Se}$ & 439 \\
\hline 21 & 43.41 & $\begin{array}{l}\text { 2,9-Bis(5-tertbutyl2hydroxy-3-pyridylphenyl)1,1-0- } \\
\text { phenanthroline }\end{array}$ & $\mathrm{C}_{42} \mathrm{H}_{38} \mathrm{~N}_{4} \mathrm{O}_{2}$ & 630 \\
\hline 22 & 44.34 & $\begin{array}{l}\text { 1-Acetyl-4,4-bis[4-(3-bromopropoxy)-3,5- } \\
\text { dimethoxyphenyl]piperidine }\end{array}$ & $\mathrm{C}_{29} \mathrm{H}_{39} \mathrm{Br}_{2} \mathrm{NO}_{7}$ & 671 \\
\hline 23 & 47.79 & 13,14-Bis(methylsulfonyl) pseudaconine & $\mathrm{C}_{27} \mathrm{H}_{45} \mathrm{NO}_{12} \mathrm{~S}_{2}$ & 639 \\
\hline 24 & 49.82 & $\begin{array}{c}\text { 2,7,12,17-Tetraethyl-3,5:8,10:13,15:18,20-tetrakis(2,2- } \\
\text { dimethylpropano)porphyrin }\end{array}$ & $\mathrm{C}_{48} \mathrm{H}_{62} \mathrm{~N}_{4}$ & 694 \\
\hline 25 & 50.82 & $\begin{array}{l}\text { 4,5,6,7-Tetrakis(p-chlorophenoxy) } 1,2- \\
\text { diiminoisoindoline }\end{array}$ & $\mathrm{C}_{32} \mathrm{H}_{19} \mathrm{C}_{14} \mathrm{~N}_{3} \mathrm{O}_{4}$ & 649 \\
\hline 26 & 51.27 & $\begin{array}{l}\text { N,N-Bis[2-[3,5-bis(ethoxycarbonyl)phenoxy]ethyl]-p- } \\
\text { toluenesulfonamide }\end{array}$ & $\mathrm{C}_{35} \mathrm{H}_{41} \mathrm{NO}_{12} \mathrm{~S}$ & 699 \\
\hline 27 & 53.41 & 5Acetoxyoctaethylporphyrin & $\mathrm{C}_{38} \mathrm{H}_{48} \mathrm{~N}_{4} \mathrm{O}_{2}$ & 592 \\
\hline
\end{tabular}


Table (3). Area percent of active compounds in garlic bulb extract treated by $\mathrm{ZnO}$ NPs and Se NPs under saline stress conditions.

\begin{tabular}{|c|c|c|c|c|c|c|c|c|}
\hline \multirow{3}{*}{ PN } & \multirow{3}{*}{ RT } & \multicolumn{7}{|c|}{ Area percent (\%) } \\
\hline & & \multirow{2}{*}{ Control } & \multicolumn{3}{|c|}{ ZnO NPs (ppm) } & \multicolumn{3}{|c|}{ Se NPs (ppm) } \\
\hline & & & 0.5 & 1 & 2 & 0.5 & 1 & 2 \\
\hline 1 & 5.07 & 3.66 & 4.11 & 5.34 & 5.89 & 5.48 & 6.10 & 6.22 \\
\hline 2 & 5.13 & 6.69 & 7.10 & 7.61 & 7.72 & 7.20 & 7.22 & 7.61 \\
\hline 3 & 5.29 & 2.18 & 2.66 & 2.78 & 3.10 & 5.28 & 6.65 & 6.23 \\
\hline 4 & 5.32 & 1.71 & 2.33 & 2.39 & 2.45 & 2.10 & 2.13 & 2.24 \\
\hline 5 & 5.41 & 2.58 & 2.15 & 2.07 & 2.01 & 3.48 & 3.09 & 2.92 \\
\hline 6 & 5.47 & 1.39 & 3.77 & 3.78 & 3.52 & 2.63 & 2.21 & 2.14 \\
\hline 7 & 6.30 & 1.94 & 2.59 & 2.46 & 2.41 & 2.48 & 2.44 & 2.36 \\
\hline 8 & 7.03 & 2.3 & 3.82 & 3.78 & 3.35 & 1.60 & 1.40 & 1.42 \\
\hline 9 & 8.87 & 1.11 & 1.52 & 1.49 & 1.47 & 1.55 & 1.65 & 1.64 \\
\hline 10 & 9.90 & 1.81 & 2.74 & 2.68 & 2.67 & 2.76 & 2.84 & 2.68 \\
\hline 11 & 10.11 & 1.98 & 2.74 & 2.67 & 2.70 & 2.57 & 2.44 & 2.40 \\
\hline 12 & 12.51 & 1.52 & 2.11 & 2.03 & 1.89 & 2.55 & 2.51 & 2.20 \\
\hline 13 & 13.61 & 1.63 & 2.34 & 2.25 & 2.23 & 2.18 & 2.14 & 2.26 \\
\hline 14 & 14.27 & 1.79 & 2.88 & 2.85 & 2.46 & 2.51 & 2.67 & 2.68 \\
\hline 15 & 14.7 & 1.59 & 2.23 & 2.25 & 2.37 & 2.22 & 2.14 & 2.15 \\
\hline 16 & 19.19 & 2.05 & 4.11 & 3.68 & 3.64 & 2.67 & 2.55 & 2.51 \\
\hline 17 & 20.36 & 1.59 & 2.21 & 2.07 & 2.11 & 2.13 & 1.91 & 1.87 \\
\hline 18 & 34.18 & 2.01 & 3.40 & 2.55 & 2.48 & 2.89 & 2.52 & 2.43 \\
\hline 19 & 41.04 & 1.09 & 1.88 & 1.97 & 2.09 & 1.56 & 2.01 & 2.16 \\
\hline 20 & 41.54 & 1.30 & 3.11 & 3.86 & 3.91 & 1.75 & 1.81 & 1.95 \\
\hline 21 & 43.41 & 1.09 & 1.69 & 1.86 & 1.94 & 1.74 & 1.95 & 2.12 \\
\hline 22 & 44.34 & 1.11 & 1.68 & 1.84 & 2.01 & 1.35 & 1.66 & 1.74 \\
\hline 23 & 47.79 & 1.24 & 1.62 & 1.68 & 1.83 & 1.35 & 1.39 & 1.57 \\
\hline 24 & 49.82 & 1.61 & 2.37 & 2.48 & 2.70 & 2.18 & 2.21 & 2.39 \\
\hline 25 & 50.82 & 1.88 & 2.21 & 2.49 & 2.88 & 2.43 & 2.67 & 2.61 \\
\hline 26 & 51.27 & 1.53 & 1.80 & 1.86 & 1.94 & 1.90 & 2.11 & 2.31 \\
\hline 27 & 53.41 & 1.01 & 1.65 & 1.78 & 1.81 & 1.68 & 1.79 & 1.97 \\
\hline
\end{tabular}

Egyptian J. Desert Res., 71, No. 1, 99-128 (2021) 


\section{Antioxidant Activity}

\subsection{DPPH radical scavenging assay}

Data presented in fig. (7a) demonstrate the effect of $\mathrm{ZnO} \mathrm{NPs}$ and $\mathrm{Se}$ NPs on scavenging rates of DPPH free radical in garlic bulbs extract under saline stress conditions. The results showed that garlic extracts have a high ability to get rid of free radicals, in addition to the use of nano compounds represented in zinc oxide and selenium nanoparticles, which led to a high increase in the elimination of these free radicals. Among these, all Se NPs treatments showed the highest potential to scavenge DPPH, compared with the control and $\mathrm{ZnO}$ NPs. The maximum scavenging of DPPH was recorded at Se NPs (2 ppm). DPPH is a stable free radical at room temperature and accepts an electron or hydrogen radical to form a stable diamagnetic molecule. The reduction capability of DPPH radicals was determined by the decrease in its absorbance at $517 \mathrm{~nm}$, which is induced by antioxidants. DPPH stable free radical method is an easy, rapid and sensitive way to evaluate the antioxidant activity of a specific compound or plant extracts (Omale and Okafor, 2008). The DPPH scavenging assay measures capacity of the extract to donate hydrogen to the DPPH radical, subsequently bleaching of the DPPH solution occurs. The DPPH solution is decolorized when an odd electron is paired off in its presence thereby reducing absorbance. Therefore, change in color from deep violet to yellow is visualized. The degree of absorbance reduction indicates the free radical scavenging ability of the particular extract. The significant decrease in the concentration of DPPH radical is due to the scavenging ability of garlic extracts (Nagulendran et al., 2007). The result of the rapid radical scavenging screening confirmed their high radical scavenging activity (Narendhirakannan and Rajeswar, 2010). Garlic extract is a promising source of antioxidants and encompasses ability to protect against free radicals (Fawad et al., 2012). Phytoceutics in garlic may act synergistically to exert antioxidant potential by scavenging reactive oxygen species, improving the activities of cellular antioxidative enzymes (glutathione peroxidase, catalase and superoxide dismutase) and also increasing the glutathione concentration in the cells (Awan et al., 2019).

\subsection{Hydrogen peroxide scavenging Assay}

Ability of the garlic bulbs extracts to scavenge hydrogen peroxide is shown in (Fig. 7b). The effect of ZnO NPs and Se NPs on scavenging rates of $\mathrm{H}_{2} \mathrm{O}_{2}$ free radical in garlic bulbs extract under saline stress conditions showed higher scavenging activity compared with control, whereas the maximum scavenging activity of $\mathrm{H}_{2} \mathrm{O}_{2}$ were recorded by Se NPs at $1 \mathrm{ppm}$ and $0.5 \mathrm{ppm}$, respectively. Hydrogen peroxide is a weak oxidizing agent and 
can inactivate a few enzymes directly, usually by oxidation of essential thiol (-SH) groups. Hydrogen peroxide can cross cell membranes rapidly, once inside the cell, $\mathrm{H}_{2} \mathrm{O}_{2}$ can probably react with $\mathrm{Fe}^{2+}$ and possibly $\mathrm{Cu}^{2+}$ ions to form hydroxyl radical and this may be the origin of many of its toxic effects. It is therefore biologically advantageous for cells to control the amount of hydrogen peroxide that is allowed to accumulate. In this respect, selenium supplementation to plants enhance the production and quality of edible plant products, by increasing antioxidant activity of plants (Abul-Soud and AbdElrahman, 2016). In addition, Germ et al. (2007) reported that, in the senescing plants, the addition of Se strengthens the antioxidative capacity by preventing the reduction of tocopherol concentration and by enhancing superoxide dismutase activity which decrease $\mathrm{H}_{2} \mathrm{O}_{2}$ radicals. Senescence processes are partly delayed due to enhanced antioxidation, which is associated with an increase of glutathione peroxidase activity. Moreover, zinc deficiency leads to physiological stress incidence mainly due to disturbance in several enzymatic systems, reduced growth and yield components, and increased ROS levels (Torabian et al., 2016 and Vojodi et al., 2017).

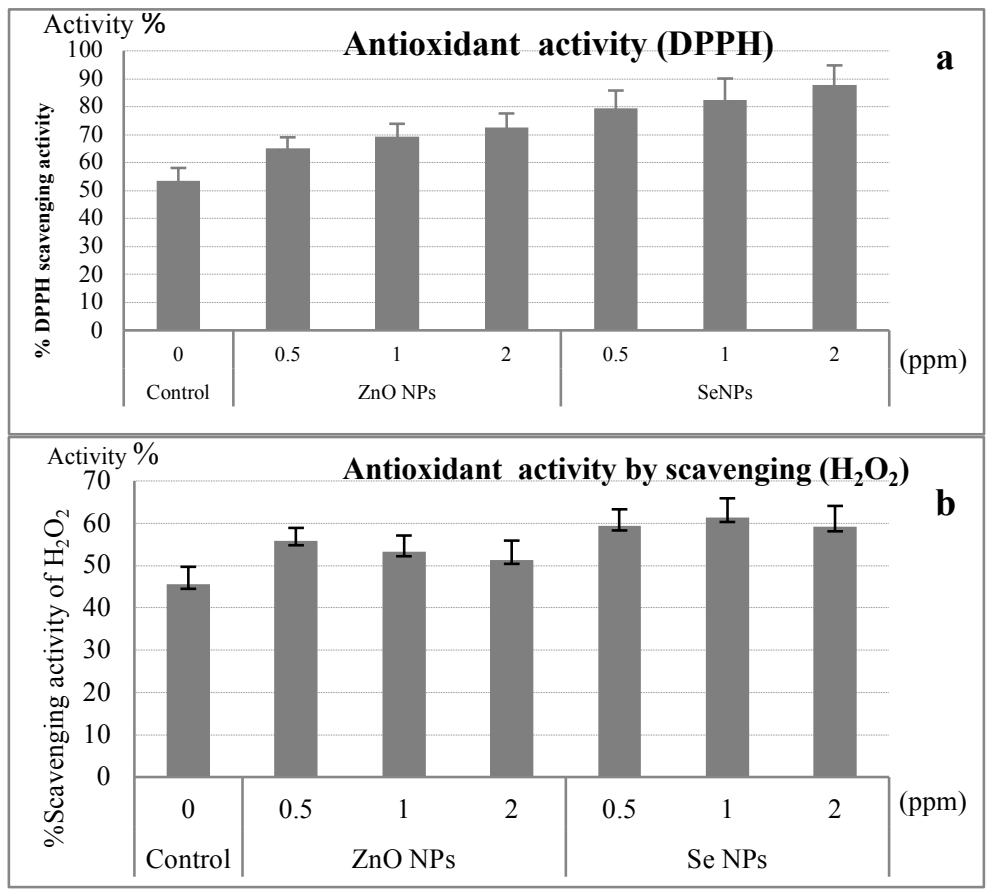

Fig. (7). Effect of ZnO NPs and Se NPs on scavenging of (a) DPPH and (b) $\mathrm{H}_{2} \mathrm{O}_{2}$ in garlic bulb extract under saline stress conditions.

Egyptian J. Desert Res., 71, No. 1, 99-128 (2021) 


\section{CONCLUSION}

It can be concluded from this study that ZnO NPs and Se NPs were synthesized by a very simple and efficient precipitation method using Moringa oleifera leaf extract as a natural precursor. The main advantage of this synthesis (green synthesis) is its simple, cost-effective synthetic route and eco-friendly. In addition, the exogenous spray of these NPs significantly ameliorates the harmful effect of saline stress and increasing the growth, yield, active compounds, and antioxidant activity of garlic plants (Sids 40) cultivated under saline conditions.

\section{REFERENCES}

Abbas, H.S. and D.H. Abou Baker (2020). Biological evaluation of selenium nanoparticles biosynthesized by Fusarium semitectum as antimicrobial and anticancer agents. Egypt. J. Chem., 63 (4): 11191133.

Abul-Soud, M.A. and S.H. Abd-Elrahman (2016). Foliar selenium application to improve the tolerance of eggplant grown under salt stress conditions. Int. J. Plant Soil Sci., 9 (1): 1-10.

Ahmed, S., M. Ahmad, B.L. Swami and S. Ikram (2016). A review on plants extract mediated synthesis of silver nanoparticles for antimicrobial applications: A green expertise. Adv. Res., 7: 17-28.

Ali, M. and I.S. Ibrahim (2019). Phytochemical screening and proximate analysis of garlic (Allium Sativum). An arch. Org. Inorg. Chem. Sci., 4 (1): 478-481.

Allen, J. (2009). Garlic production. Factsheet, Garlic Production, Order Number 97-007.

Almeida, C.L.F.D., H.D.S. Falcao, G.R.D.M. Lima, C.D.A. Montenegro, N.S. Lira, P.F.D. Athayde-Filho, L.C. Rodrigues, M.D.F.V. Souza, J.M. Barbosa-Filho and L.M. Batista (2011). Bioactivities from marine algae of the genus Gracilaria. Int. J. Mol. Sci., 12: 45504573.

Al-Zohiri, S.S.M. (2009). Amelioration the adverse effect of irrigation water salinity on growth, yield and its quality of garlic plants by application of some antioxidants. The Fifth Int. Conf. Sustain. Agric. Develop., Fac. Agric., Fayoum Univ., 21-23 Dec., pp. 41-55.

Ameh, G.I., S.C. Eze and F.U. Omeje (2013). Phytochemical screening and antimicrobial studies on the methanolic bulb extract of Allium sativum L. Afr. J. Biotech., 12 (14): 1665-1668. 
Aromal, S.A., V.K. Vidhu and D. Philip (2012). Green synthesis of welldispersed gold nanoparticles using Macrotyloma uniflorum. Spectrochim. Acta, Part A, 85: 99-104.

Arunachalam, K.D., S.K. Annamalai and S. Hari (2013). One-step green synthesis and characterization of leaf extract-mediated biocompatible silver and gold nanoparticles from Memecylon umbellatum. Int. J. Nanomed., 8: 1307-1315.

Astaneh, R.K., S. Bolandnazar, F.Z. Nahandi and S. Oustan (2018). The effects of selenium on some physiological traits and $\mathrm{K}, \mathrm{Na}$ concentration of garlic (Allium sativum L.) under $\mathrm{NaCl}$ stress. Inf. Process. Agric., 5 (1315): 156-161.

Astaneh, R.K., S. Bolandnazar, F. Nahandi and S. Oustan (2019). Effects of selenium on enzymatic changes and productivity of garlic under salinity stress. Afr. J. Bot., 121: 447-455.

Awan, K.A., M.S. Butt, I. UlHaq and H.A.R. Suleria (2019). Investigating the antioxidant potential of garlic (Allium sativum) extracts through different extraction modes. Curr. Bioact. Compd., 15 (1): 45-50.

Ayad, H.S., F. Reda and M.S.A. Abdalla (2010). Effect of putrescine and zinc on vegetative growth, photosynthetic pigment, lipid peroxidation and essential oil content of geranium. Agric. Sci., 6 (5): 601-610.

Ayaz, E., I. Turel, A. Gul and O. Yilmaz (2008). Evaluation of the anthelmentic activity of garlic (Allium sativum) in mice naturally infected with Aspiculuris tetraptera. Recent Pat. Antiinfect. Drug Discov., 3: 149-152.

Babalar, M., S. Mohebbi, Z. Zamani and M.A. Askari (2019). Effect of foliar application with sodium selenate on selenium biofortification and fruit quality maintenance of Starking Delicious apple during storage. J. Sci. Food Agric., 99: 5149-5156.

Banaee, M., S. Tahery, H.B. Nematdoost, S. Shahafve and M. Vaziriyan (2019). Blood biochemical changes in common carp (Cyprinus carpio) upon co-exposure to titanium dioxide nanoparticles and paraquat. Iran J. Fish Sci., 18: 242-255.

Begum, N.A., S. Mondal and R.A. Basu Laskar (2009). Biogenic synthesis of $\mathrm{Au}$ and $\mathrm{Ag}$ nanoparticles using aqueous solutions of black tea leaf extracts, Biointer., 71: 113-118.

Blasco, B., N.S. Graham and M.R. Broadley (2015). Antioxidant response and carboxylate metabolism in Brassica rapa exposed to different external Zn, Ca, and Mg supply. J. Plant Physiol., 176: 16-24.

Block, E. (1992). The organosulfur chemistry of the genus Allium implications for the organic chemistry of sulfur. Angew. Chem., 31:

Egyptian J. Desert Res., 71, No. 1, 99-128 (2021) 
$1135-1178$.

Boudet, A.M. (2007). Evolution and current status of research in phenolic compounds. Phytochem., 68: 2722-2735.

Bozin, B., N. Mimica-Dukic, I. Samojlik, A. Goran and R. Igic (2008). Phenolics as antioxidants in garlic (Allium sativum L., Alliaceae). Food Chem., 111 (4): 925-929.

Cakmak, I. (2000). Possible roles of zinc in protecting plant cells from damage by reactive oxygen species. New Phytol., 146: 185-205.

Cai, S. and R.B. Sing (2004). A distinct utility of the amide III infrared band for secondary structure estimation of aqueous protein solutions using partial least squares methods, Biochem., 43: 2541-2549.

Cai, Y., Q. Luo, M. Sun and H. Corke (2004). Antioxidant activity and phenolic compounds of 112 Chinese medicinal plants associated with anticancer. Life Sci., 74: 2157-2184.

Chiou, Y.D. and Y.J. Hsu (2011). Advances in nanotechnology research and application: 2012 Ed., Appl. Cataly. Environ., B, 105: 211-219.

Deresse, D. (2010). Antibacterial effect of garlic (Allium sativum) on Staphylococcus aureus: An in vitro study. Asian J. Med. Sci., 2 (2): $62-65$

El-Saber, M.M., R. El-Massry, H. Kamel and M. Hendawey (2016). Emino amino acids accumulation and its implication in barley tolerance to salt stress under ras sudr conditions, South saini, Egypt. Zag. J. Agric. Res., 43: 533-554.

El-Saber, M.M., A.A. Mahdi, A.H. Hassan, K.Y. Farrouh and A. Osman (2021). Effects of magnetite nanoparticles on physiological processes to alleviate salinity induced oxidative damage in wheat. J. Sci. Food Agric., 101 (6): 1-13.

El-Sayed, A.A., A. Amr, O.M.H.M. Kamel, M.M.T. El-Saidi and A.E. Abdelhamid (2020). Eco-friendly fabric modification based on AgNPs@ moringa for mosquito repellent applications. Cellulose, 27 (14): 8429-8442.

El-Zemity, S., H. Rezk, S. Farok and A. Zaitoon (2006). Acaricidal activities of some essential oils and their monoterpenoidal constituents against house dust mite, Dermatophagoides pteronyssinus (Acari: Pyroglyphidae). J. Zhejiang Univ. Sci., 7: 957962.

Farroh, K.Y., A.A. Mahdi, A. Osman, A. Hassan and M.M. El-Saber (2020). Impact of chemically synthesized zinc oxide nanoparticles on saline stressed wheat. Plant Cell Biotechnol. Mol. Biol., 21 (65\&66): 117136. 
Fawad, S.A., N. Khalid, W. Asghar and H.A.R. Suleria (2012). In vitro comparative study of Bougainvillea spectabilis "stand" leaves and Bougainvillea variegata leaves in terms of phytochemicals and antimicrobial activity. Chinese J. Nat. Med., 10 (6): 441-447.

Gao, X., J. Zhang and L. Zhang (2002). Hollow sphere selenium nanoparticles: their in-vitro antihydroxyl radical effect. Adv. Mater., 14: $290-293$

Germ, M, V. Stibilj and I. Kreft (2007). Metabolic importance of selenium for plants. Eur. J. Plant Sci. Biotech.,1: 91-97.

Gholizadeh, Z.T.B., M. Banaee, A.Y. Jourdehi, B.N. Haghi and M.H.S. Hassani (2019). Effects of dietary selplex supplement on growth performance, hematological and immunological parameters in Siberian sturgeon (Acipenser baerii Brandt, 1869). Iran J. Fish Sci., 18: 830-846.

Gill, S.S. and N. Tuteja (2010). Reactive oxygen species and antioxidant machinery in abiotic stress tolerance in crop plants. Plant Physiol. Biochem., 48: 909-930.

Gomez, K.A. and A.A. Gomez (1984). In: "Statistical Procedures for Agricultural Research". John Wiley \& Sons. ( $2^{\text {nd }} E d$.). New York: Wiley, $680 \mathrm{p}$.

Hasanuzzaman, M., M.A. Hossain and M. Fujita (2011). Selenium-induced up-regulation of the antioxidant defense and methylglyoxal detoxification system reduces salinity-induced damage in rapeseed seedlings. Biol. Trace Elem. Res., 143: 1704-1721.

Huang, B., J. Zhang, J. Hou and C. Chen (2003). Free radical scavenging efficiency of nano-Se in vitro. Free Radic. Bio. Med., 35: 805-813.

Ibrahim, A.T.A. (2020). Toxicological impact of green synthesized silver nanoparticles and protective role of different selenium type on Oreochromis niloticus: hematological and biochemical response. J. Trace Elem. Med. Biol., 61: 1-9.

Ibrahim, T.A., I.B.O. Dada and R.A. Adejare (2010). Comparative phytochemical properties of crude ethanolic extracts and physicochemical characteristics of essential oils of Myristical fragrans (nutmeg) seeds and Zingiber officinate (ginger) roots. Electronic J. Environ. Agric. Food Chem., 9 (6): 1110-1116.

Ibrahim, A., M. Banaee and A. Sureda (2019). Selenium protection against mercury toxicity on the male reproductive system of Clarias gariepinus. Comp. Biochem. Physiol. Toxicol. Pharmacol., 225: 1-8.

Iqbal, M., I. Hussain, H. Liaqat, M.A. Ashraf, R. Rasheed and A.U. Rehman (2015). Exogenously applied selenium reduces oxidative stress and induces heat tolerance in spring wheat. Plant Physiol. Biochem., 94:

Egyptian J. Desert Res., 71, No. 1, 99-128 (2021) 
95-103.

Jan, A.U. and F. Hadi (2015). Potassium, zinc and $\mathrm{GA}_{3}$ foliar application enhanced salinity stress tolerance, proline and total phenolic contents in sunflower. Am. Eurasian J. Agric. Environ. Sci., 15 (9): $1835-1844$.

Jiang, C., C. Zu, D. Lu, Q. Zheng, J. Shen, H. Wang and D. Li (2017). Effect of exogenous selenium supply on photosynthesis, $\mathrm{Na}+$ accumulation and antioxidative capacity of maize (Zea mays L.) under salinity stress. Sci. Rep., 7: 1-14.

Kalishwaralal, K., V. Deepak, S.B.R.K. Pandian, M. Kottaisamy, S.B. Kanth, B. Kartikeyan and S. Gurunathan (2010). Biosynthesis of silver and gold nanoparticles using Brevibacterium casei. Colloids and Surfaces, B: Biointerfaces, 77: 257-262.

Kamran, M., A. Parveen, S. Ahmar, Z. Malik, S. Hussain, M. S. Chattha, M. H. Saleem, M. Adil, P. Heidari and J. Chen (2020). An Overview of hazardous impacts of soil salinity in crops, tolerance mechanisms, and amelioration through selenium supplementation. Int. J. Mol. Sci., 21 (148): 1-27.

Kannan, S., K. Mohanraj, K. Prabhu, S. Barathan and G. Sivakumar (2014). Synthesis of selenium nanorods with assistance of biomolecule. Bull. Mater. Sci., 37: 1631-1635.

Kaur, N., S. Sharma, S. Kaur and H. Nayya (2014). Selenium in agriculture: A nutrient or contaminant for crops. Agron. Soil Sci., 60: 15931624.

Kirtee, W., A. Choudhari, R. Chikate, and R. Kaul-Ghanekar (2013). Synthesis and characterization of gold nanoparticles using Ficus religiosa extract. Carbon Sci. Techn., 5: 203-210.

Kopec, A., J. Skoczylas, E. Jedrszczyk, R. Francik, B. Bystrowska and J. Zawistowski (2020). Chemical composition and concentration of bioactive compounds in garlic cultivated from air bulbils. Agric., 10 (40): $1-15$.

Ledezma, E. and R. Apitz-Castro (2006). Ajoene the main active compound of garlic (Allium sativum): a new antifungal agent. Iberoam. Micol., 23 (2): 75-80.

Mahdi, A.A., M.M. El-Saber, A. Osman, A. Hassan and K.Y. Farroh (2020). Toxicological and significant execute of biocompatible $\mathrm{CuO}$ nanoparticles and their influences on biochemical and molecular markers of wheat genotypes under saline conditions. IOSR Journal of Biotechnology and Biochemistry, 6: 58-68. 
Matinise, N., X.G. Fuku, K. Kaviyarasu, N. Mayedwa and M. Maaza (2017). $\mathrm{ZnO}$ nanoparticles via Moringa oleifera green synthesis: Physical properties and mechanism of formation. Appl. Surf. Sci., 406: 339347.

Mehrabani, L.V., R.V. Kamran, M.B. Hassanpouraghdam and M. Pessarakli (2017). Zinc sulfate foliar application effects on some physiological characteristics and phenolic and essential oil contents of (Lavandula stoechas L.) under sodium chloride $(\mathrm{NaCl})$ salinity conditions. Commun. Soil Sci. Plant Anal., 48 (16): 1860-1867.

Mnayer, D., A.S. Fabiano-Tixier, E. Petitcolas, T. Hamieh, N. Nehme, C. Ferrant, X. Fernandez and F. Chemat (2014). Chemical composition, antibacterial and antioxidant activities of six essentials oils from the Alliaceae family. Molecules, 19: 20034-20053.

Nagulendran, K.R., S. Velavan, R. Mahesh and V.H. Begum (2007). In Vitro antioxidant activity and total polyphenolic content of Cyperus rotundus Rhizomes. J. Chem., 4 (3): 440-449.

Narendhirakannan, R.T. and K. Rajeswar (2010). In vitro antioxidant properties of three varieties of Allium Sativum L. extracts. J Chem., 7 (1): 573-579.

Oktay, M., İ. Gülçin and Ö.İ. Küfrevioğlu (2003). Determination of in vitro antioxidant activity of fennel (Foeniculum vulgare) seed extracts. LWT-Food Sci. Techn., 36 (2): 263-271.

Omale, J. and P.N. Okafor (2008). Comparative antioxidant capacity, membrane stabilization, polyphenol composition and cytotoxicity of the leaf and stem of Cissus multistriata. African J. Biotechnol., 27 (17): 3129-3133.

Pal, S., S. Mondal, J. Maity and R. Mukherjee (2018). Synthesis and characterization of $\mathrm{ZnO}$ nanoparticles using Moringa oleifera leaf extract: Investigation of photocatalytic and antibacterial activity. Int. J. Nanosci. Nanotechnol., 14 (2): 111-119.

Parashar, U.K., P.S. Saxena and A. Srivastava (2009). Bioinspired synthesis of silver nanoparticles, Dig. J. Nanomater. Biostruc., 4: 159-166.

Philip, D. (2010). Honey mediated green synthesis of gold nanoparticles. Spectrochim. Acta, Part A: Mol. Biomolec. Spectrosc., 73: 650-653.

Ramamurthy, C.H., K.S. Sampath, P. Arunkumar, M.S. Kumar, V. Sujatha, K. Premkumar and C. Thirunavukkarasu (2013). Green synthesis and characterization of selenium nanoparticles and its augmented cytotoxicity with doxorubicin on cancer cells. Bioprocess Biosyst. Eng., 36: 1131-1139.

Egyptian J. Desert Res., 71, No. 1, 99-128 (2021) 
Ramasasa, C. (2009). Garlic used as an effective insecticide, World Health Organization 1991. Guide lines for the assessment of herbal medicine. WHO/ TRM/ 91. Geneva: World Health Organization.

Rastogi, L. and J. Arunachalam (2011). Sunlight based irradiation strategy for rapid green synthesis of highly stable silver nanoparticles using aqueous garlic (Allium sativum) extract and their antibacterial potential. Mater. Chem. Phys., 129: 558-563.

Reda, F., M.T. Abdelhamid and S.R. El-Lethy (2014). The role of $\mathrm{Zn}^{2+}$ and B for improving Vicia faba L. tolerance to salinity stress. Middle East J. Agric. Res., 3 (4): 707-714.

Romeilah, R.M., S.A. Fayed and G.I. Mahmoud (2010). Chemical compositions, antiviral and antioxidant activities of seven essential oils. J. Appl. Sci. Res., 6: 50-62.

Ruch, R.J., S.J. Cheng and J.E. Klaunig (1989). Prevention of cytotoxicity and inhibition of intercellular communication by antioxidant catechins isolated from Chinese green tea. Carcinogenesis, 10 (6): 1003-1008.

Salama, Y., A.M., N.M.K. Hassan, S.A. Saleh and M.F. Zaki (2012). Zinc amelioration effects on tomato growth and production under saline water irrigation conditions. J. Appl. Sci. Res., 8 (12): 5877-5885.

Salama, Z.A., A.A. Gaafar and M.M. El Fouly (2015). Genotypic variations in phenolic, favonoids and their antioxidant activities in maize plants treated with Zn (II) HEDTA grown in salinized media. Agric. Sci., 6: 397-405.

Siddiqui, H., K.B.M. Ahmed and S. Hayat (2018). Comparative effect of 28homobrassinolide and 24-epibrassinolide on the performance of different components influencing the photosynthetic machinery in Brassica juncea L. Plant Physiol. Biochem., 129: 198-212.

Sieprawska, A., A. Korna's and M. Filek (2015). Involvement of selenium in protective mechanisms of plants under environmental stress conditions-Review. Acta Biol. Crac. Ser. Bot., 57: 9-20.

Singh, V. and R. Kumar (2017). Study of phytochemical analysis and antioxidant activity of Allium sativum of bundelkhand region. Int. J. Life Sci. Res., 3 (6): 1451-1458.

Sirelkhatim, A., M. Shahrom, S. Azman, H.M.K. Noor, A.L. Chuo, K.M.B. Siti, H. Habsah and M. Dasmawati (2015). Review on zinc oxide nanoparticles: antibacterial activity and toxicity mechanism. Micro Nano Lett., 7 (3): 219-242.

Slimestad, R., T. Fossen and I.M. Vagen (2007). Onions: a source of unique dietary flavonoids. J. Agric. Food Chem., 55 (25): 10067-10080. 
Song, C.Z., M.Y. Liu, J.F. Meng, M. Chi, Z.M. Xi and Z.W. Zhang (2015). Promoting effect of foliage sprayed zinc sulfate on accumulation of sugar and phenolics in berries of Vitis vinifera $\mathrm{Cv}$. Merlot growing on zinc deficient soil. Molecules, 20: 2536-2554.

Sujitha, M.V. and S. Kannan (2013). Green synthesis of gold nanoparticles using Citrus fruits (Citrus Limon, Citrus Reticulata and Citrus Sinensis) aqueous extract and its characterization. Spectrochim. Acta Part A: Molec. Biomolec. Spectrosc., 102: 15-23.

Suleria, H.A., R. Sadiq, M. Butt, F.M. Anjum, F. Saeed, R. Batool and A.N. Ahmad (2012). Aqueous garlic extract and its phytochemical profile; special reference to antioxidant status. Int. J. Food Sci. Nutr., 63 (4): 431-439.

Swetha, T.V., S. Rajeshkumar, T. Lakshmi and A. Roy (2019). Zinc oxide nanoparticles green synthesis using Moringa oleifera and tulasi a formulation and its anti-inflammatory activity. Drug Invention Today., 11 (10): 2366-2369.

Tamuly, C., M. Hazarika, S.C. Borah, M.R. Das and M.P. Boruah (2013). In situ biosynthesis of Ag, Au and bimetallic nanoparticles using Piper pedicellatum. DC: Green chemistry approach. Colloids and Surfaces B: Bio-Interfaces, 102: 627-634.

Thalooth, A.T., M.M. Tawfik and M.H. Mohamed (2006). A comparative study on the effect of foliar application of zinc, potassium and magnesium on growth, yield and some chemical constituents of mungbean plants grown under water stress conditions. World J. Agric. Sci., 2 (1): 37-46.

Thomas, E., T. Aneesh, D. Thomas and R. Anandan (2013). GC-MS analysis of phytochemical compounds present in the rhizomes of Nervilia aragoana Gaud. Asian J. Pharm. Clin. Res., 6 (3): 68-74.

Torabian, S., M. Zahedi and A. Khoshgoftarmanesh (2016). Effects of foliar spray of zinc oxide on some antioxidant enzymes activity of sunflower under salt stress. J. Agric. Sci. Tech., 18 (4): 1013-1025.

Turakainen, M., H. Hartikainen and M. Seppänen (2004). Effects of selenium treatments on potato (Solanum tuberosum L.) growth and concentrations of soluble sugars and starch. J. Agric. Food. Chem., 52: $5378-5382$.

Vadlapudi, V. (2014). Green synthesis of silver and gold nanoparticles. Middle-East J.Sci. Res., 19: 834-842.

Van Zelm, E., Y. Zhang and C. Testerink (2020). Salt tolerance mechanisms of plants. Annu. Rev. Plant Biol., 71: 403-433.

Versini, A., P. Di Tullo, E. Aubry, M. Bueno, Y. Thiry, F. Pannier and M. Castrec-Rouelle (2016). Influence of Se concentrations and species

Egyptian J. Desert Res., 71, No. 1, 99-128 (2021) 
in hydroponic cultures on Se uptake, translocation and assimilation in non-accumulator ryegrass. Plant Physiol. Biochem., 108: 372380.

Voigt, C.E. (2004). Glorious Garlic Herb of the Year. Journal of International Herb, pp. 1-6. Association Horticulture Committee, Virginia State University.

Vojodi, M.L., R.V. Kamran, M.B. Hassanpouraghdam and M. Pessarakli (2017). Zinc sulfate foliar application effects on some physiological characteristics and phenolic and essential oil contents of Lavandula stoechas L. under sodium chloride $(\mathrm{NaCl})$ salinity conditions. Commun. Soil Sci. Plant Anal., 48 (16): 1860-1867.

Wani, A.S., A. Ahmad, S. Hayat and I. Tahir (2019). Epibrassinolide and proline alleviate the photosynthetic and yield inhibition under salt stress by acting on antioxidant system in mustard. Plant Physiol. Biochem., 135: 385-394.

Zafar, S., Z. Hasnain, N. Aslam, S. Mumtaz, H.Z.E. Jaafar, P.E.M. Wahab, M. Qayum and A.N. Ormenisan (2021). Impact of Zn nanoparticles synthesized via green and chemical approach on Okra (Abelmoschus esculentus L.) growth under salt stress. Sustainability, 13 (7): 1-12.

Zhang, J., H. Wang, X. Yanand and L. Zhang (2005). Comparison of shortterm toxicity between nano-Se and selenite in mice. Life. Sci., 76: 1099-1109.

Zhao, N.N., H. Zhang, X.C. Zhang, X.B. Luan, C. Zhou, Q.Z. Liu, W.P. Shi and Z.L. Liu (2013). Evaluation of acute toxicity of essential oil of garlic (Allium sativum) and its selected major constituent compounds against overwintering Cacopsylla chinensis (Hemiptera: Psyllidae). J. Econ. Entomol., 106: 1349-1354. 


\section{تأثير جزيئات الزنك والسلينيوم النانوية المخلقة حيويًا على الإنتاجية والمواد

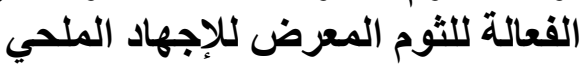

مصرد محود محمد الصابير ميمياء الحيوية، قسم الأصول الور اثية، مركز بحوث الصحر اء، المطرية، القاهرة،

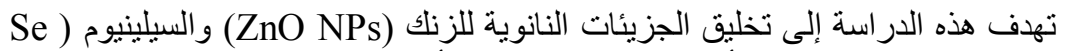

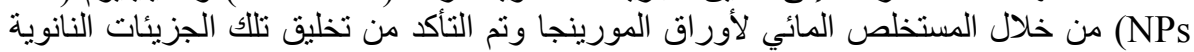

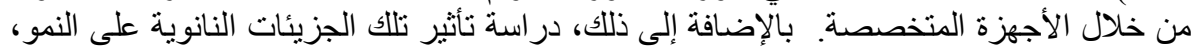

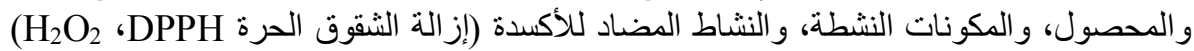

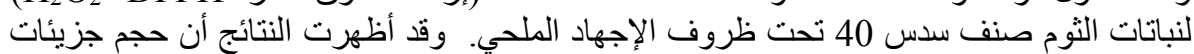

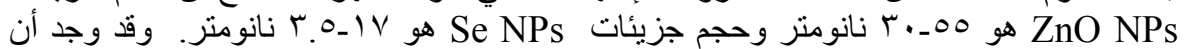

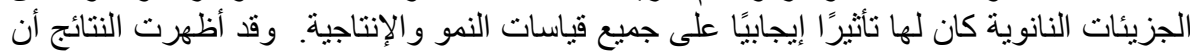

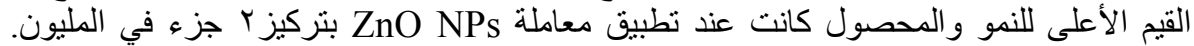

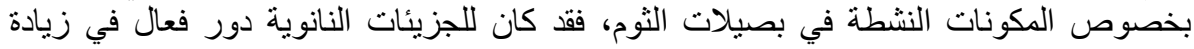

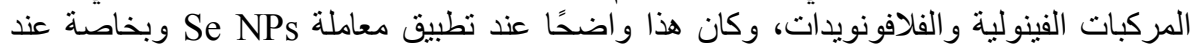

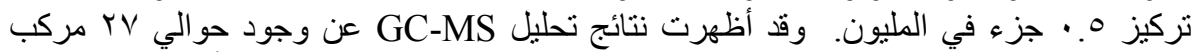

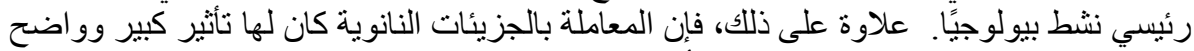

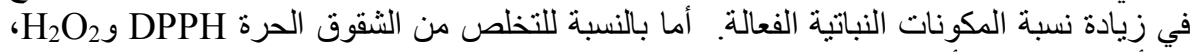

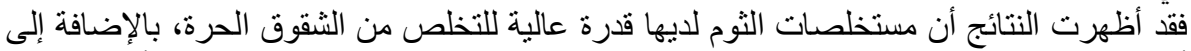

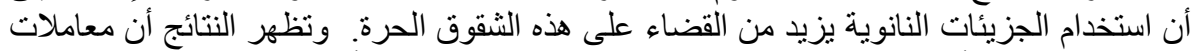
كانت الأفضل مقارنة بـ Se NPs سو $\mathrm{H}_{2} \mathrm{O}_{2}$

Egyptian J. Desert Res., 71, No. 1, 99-128 (2021) 